\title{
Interleukin 28B rs 12979860 CT, rs 12980275 GA, rs8099917 GT and $T T$ genotypes are the Predictors of Rapid Viral Response in Hepatitis C Virus-Infected Patients
}

\author{
Hepatit C Virüs Enfeksiyonu Olan Hastalarda Interlökin 28B rs 12979860 CT, rs 12980275 GA, \\ rs8099917 GT ve TT Genotipleri Hızlı Viral Yanıtın Göstergesidir
}

\author{
1 Gaziosmanpaşa University Faculty of Medicine, Department of Medical Biology, Tokat, Turkey \\ 2Antalya Training and Research Hospital, Clinic of Internal Medicine, Allergy and Clinical Immunology Unit, Antalya, Turkey \\ ${ }^{3}$ Samsun Training and Research Hospital, Clinic of Infectious Diseases and Clinical Microbiology, Samsun, Turkey \\ ${ }^{4}$ Antalya Training and Research Hospital, Clinic of Pathology, Antalya, Turkey \\ ${ }_{5}^{5}$ Gaziosmanpaşa University Faculty of Medicine, Department of Infectious Diseases and Clinical Microbiology, Tokat, Turkey
}

Aydın RÜSTEMOĞLU1ํ, Didem YALÇIN², Özgür GÜNAL ${ }^{3}$, Betül ÇELIK ${ }^{4}$, Şener BARUT5, Ömer ATEŞ

\begin{abstract}
Objective: In this study, the effects of genotypic differences on the clinical course of the disease, response to treatment and fibrosis were investigated in patients with hepatitis $\mathrm{C}$ virus (HCV) infection. Materials and Methods: Ninety-nine chronic HCV-infected patients and 95 controls were enrolled. The patients received pegylated interferon (PeglFN) + ribavirin (RBV) for 48 weeks and followed up for the next 48 weeks. Aspartate aminotransferase/platelet ratio index was used to determine the stage of liver fibrosis. DNA specimens were extracted from peripheral blood mononuclear cells and the interleukin (IL) 28B gene rs12979860, rs12980275, and rs8099917 were genotyped by the immune polymerase chain reaction-restriction fragment length polymorphism method. Results were analysed using the SPSS 16.0 and OpenEpi 2.2 softwares. Results: All patients had HCV genotype 1. Among the $99 \mathrm{HCV}+$ patients, in $26.3 \%$ spontaneous viral clearance, in $42.8 \%$ rapid viral response, $92 \%$ early viral response and in $72.6 \%$ sustained viral response was observed. The allele frequencies of IL28B single nucleotide polymorphisms (SNP), rs12979860, rs12980275, and rs8099917 were not identical in all samples $(p<0.005)$. SNP rs12979860 CT genotype ( $\mathrm{p}=0.010) ;$ rs12980275 GA genotype $(p=0.010)$; and rs8099917 GT and $\Pi$ genotypes $(p=0.019$ and 0.020 , respectively) were strongly associated with rapid viral response in the overall sample.

Conclusion: The determination of IL28B polymorphisms may be useful to individualize treatment options when using PEG/RBVbased therapies for chronic HCV infection but genetic characteristics of populations of the countries must be known.

Keywords: Interleukin 28B, hepatitis C virus, single nucleotide polymorphisms, polymorphism, genotype
\end{abstract}

ÖZ

Amaç: Bu çalışmamızda hepatit C virüs ( $\mathrm{HCV}$ ) enfeksiyonu olan hastalarda genotipik farklılıkların hastalığın klinik gidişi, tedavi yanıtlar ve fibrosis üzerine etkileri araştııımış̦tır.

Gereç ve Yöntemler: Çalışmaya 99 kronik aktif HCV enfeksiyonu olan hasta ve 95 sağlıklı kontrol dahil edildi. Hastaların tümü 48 hafta boyunca pegile interferon (PeglFN) + ribavirin (RBV) tedavisi aldı ve tedavi sonu 48 hafta takip edildi. Karaciğer fibrosis evresi için aspartat aminotransferaz/platelet skoru kullanıldı. DNA örnekleri deneklerin peripheral kan mononükleer hücrelerinden elde edildi ve immün polimeraz zincir reaksiyonu-restriksiyon parça uzunluk polimorfizmi yöntemiyle interlökin (IL) 28B rs12979860, rs12980275 ve rs8099917 genotiplendirmeleri yapıldı. Sonuçlar SPSS 16,0 ve OpenEpi 2,2 yazılımı ile analiz edildi.

Bulgular: Tüm hastalar HCV genotip 1 hastası idi. Çalışmaya alınan deneklerde IL28B tek nükleotid polimorfizmi (TNP) (rs12979860, rs12980275 ve rs8099917 dağılımı farklılık gösteriyordu $(p<0,005)$. TNP rs12979860 CT genotipi ( $p=0,010)$; rs12980275 GA genotipi $(p=0,010)$; ve rs8099917 GT ve Tा genotipleri $(p=0,019$ ve 0,020 sırasıyla) ve hızlı viral yanıt arasında kuvvetli ilişkili bulundu.

Sonuç: Kronik HCV enfeksiyonu olan hastaların PeglFN+RBV ile tedavilerinin bireysel olarak belirlenmesinde IL28B polimorfizmlerinin bilinmesi faydalı olabilir. Fakat her ülkenin kendi genotipik karakteristiklerini bilmesi gereklidir.

Anahtar Kelimeler: Interlökin 28B, hepatit C virüs, tek nükleotid polimorfizmi, polimorfizm, genotip

Rüstemoğlu A, Yalçın D, Günal Ö, Çelik B, Barut Ş, Ateş Ö. Interleukin 28B rs12979860 CT, rs12980275 GA, rs8099917 GT and TT genotypes are the Predictors of Rapid Viral Response in Hepatitis C Virus-Infected Patients. Viral Hepat J. 2016;22:97-102.

Address for Correspondence: Özgür Günal MD, Samsun Training and Research Hospital, Clinic of Infectious Diseases and Clinical Microbiology, Samsun, Turkey E-mail: ozgurgop@yahoo.com Received: 16.09.2016 Accepted: 18.11.2016

${ }^{-}$Copyright 2016 by Viral Hepatitis Society / Viral Hepatitis Journal published by Galenos Yayinevi. 


\section{Introduction}

Hepatitis C virus $(\mathrm{HCV})$ is the etiological factor for hepatitis $\mathrm{C}$, which is one of the most important pathogenic factors of chronic liver diseases, cirrhosis and, even hepatocellular carcinoma. When infected with HCV, only a small proportion of patients clear the virus spontaneously and the majority develops chronic hepatitis $\mathrm{C}$ $(\mathrm{CHC})$ (1). There are viral and host factors that are important in the development of chronic infection. Baseline viral load, rapid virologic response (RVR) and host characteristics (e.g. alcohol consumption, steatosis, liver fibrosis, metabolic syndrome, ethnicity, and host genetic polymorphisms) are the examples that have impact on chronicity (2).

Hepatocytes are the target cell of the virus. After infection, the innate immune system reacts to the virus and after 4 to 8 weeks, $\mathrm{CD} 8+\mathrm{T}$ cells recognize viral peptides bound to human leukocyte antigen class 1 molecules on virus-infected hepatocytes. This initiates signaling pathways that lead to the synthesis of interferon (IFN) and a variety of other cytokines. IFN-lambda3 ( $\lambda 3$ ) belongs to the type 3 IFN family (IFN- $\lambda$ ). IFN- $\lambda$ is rapidly induced during $\mathrm{HCV}$ infection and has antiviral activity against HCV $(3,4)$. The virus is eliminated during the acute phase of the infection by $T$ cell-mediated antiviral mechanisms. The rate of spontaneous viral clearance in acute HCV infection is approximately $26 \%$ (range: $15 \%-40 \%)(5,6,7)$. In the remaining patients who do not defeat the virus at first glance, HCV persists for decades unless treated. Until recently, the effective treatment of chronic HCV infection includes pegylated interferon (PegIFN) and ribavirin (RBV) regimen (1). IFN, especially IFN- $\lambda 3$ interacts with its acceptor, a heterodimer [IFN$\lambda R 1 \times$ interleukin (IL)-10R2]. Even the most perfect therapeutic molecules (PeglFN+RBV) do not guarantee 100\% efficacy and sustained virologic response (SVR) remains 40\% $(2,8)$.

There are variations that contribute to therapeutic success of $\mathrm{HCV}$ infection. Genotype of HCV is the most important parameter that has impact on treatment response. Genotype 1 is regarded as "difficult-to-treat" (2). According the HCV genotypes involved, SVR rates of genotypes 2, 3, 5 and 6 is $70 \%-90 \%$, but it is less than $50 \%$ for genotypes 1 and $4(1,9,10)$. Two postdoctoral thesis including 500 and 115 patients $(11,12)$ conducted in Turkey revealed that HCV genotype $1 \mathrm{~b}$ was the most common (81.7$90 \%)$, followed by genotype 1a (5.2-7.2\%).

Besides HCV genotype, host genetic background could impact $\mathrm{HCV}$ infection, viral clearance, and treatment. Although studies demonstrated associations between cytokine gene polymorphisms and outcome of HCV infection, no general consensus has been reached, possibly due to differences between ethnic groups. Four recent studies $(13,14,15,16)$ demonstrated that predictive role of single nucleotide polymorphisms (SNPS) of the IL28B locus was more likely to be associated with spontaneous viral clearance and treatment effectiveness of HCV in genotype 1 patients who were cured by PegIFN combined with RBV: IL28B rs12979860 C (goodresponse allele) versus $\mathrm{T}$ (poor-response allele) and rs809917 T (good-response allele) versus $\mathrm{G}$ (poor-response allele) showed the strongest association with SVR.

SNPs of the IL28B gene has been extensively described in the literature but allele frequencies, in particular rs809917, differs somewhat between world-wide populations $(17,18,19,20)$. Therefore, the predictive power of SNPs may vary between different cohorts. For example rs809917 was only a weak predictor of SVR in African-American patients (13). The aim of this study was to examine the prevalence and clinical significance of the outlined SNPs in a population from Turkey, a region with a high prevalence of $\mathrm{HCV}$ infection and a high prevalence of genotype $1 \mathrm{~b}$.

\section{Materials and Methods}

A total of $99 \mathrm{HCV}$-infected patients (26 spontaneous clearance and 73 chronic HCV genotype $1 \mathrm{~b}$ patients) and 95 healthy control subjects were included in the study by Gaziosmanpaşa University Faculty of Medicine, Department of Infectious Diseases and Clinical Microbiology. CHC patients, who had received weekly injections of PegIFNepartment of Infectious Diseases and Clinical Microbiology. $\mathrm{CHC}$ patients, who had received weegIFNepartment of Infectious Diseases and Clinical Microbiology. CHC paeglFNepartment of Infectious Diseases and Clinical Microbio. $5 \mu \mathrm{g} / \mathrm{kg}$ body weight. Ribavirin was orally administered daily in two divided doses (1.000 $\mathrm{mg}$ for $\leq 75 \mathrm{~kg}, 1.200 \mathrm{mg}$ for $>75 \mathrm{~kg}$ ) (21).

Genomic DNA was extracted from blood samples using an Invitrogen Genomic DNA Isolation Mini Kit K1820-02 (Invitrogen Life Technologies, Carlsbad, CA, USA). Polymerase chain reaction (PCR) of rs 12979860, rs12980275, and rs8099917 polymorphisms of IL28B gene were performed in a total volume of $25 \mu \mathrm{L}$, using $100 \mathrm{ng}$ of genomic DNA with 20 pmol primers each (for rs12979860 F:5'-AGG GCC CCT AAC CTC TGC ACA GTC T-3', R: 5'- GCT GAG GGA CCG CTA CGT AAG TCA CC-3'; for rs12980275 F:5'- GAG AGC AAG AGG AGG GAA GGA A-3', R: 5'-GTG TGC CAT TAG CCA GTC AGA T-3'; and for rs8099917 F:5'-TTC ACC ATC CTC CTC TCA TCC CTC AT -3', R: 5'- TCC TAA ATT GAC GGG CCA TCT GTT TC-3'), $0.2 \mathrm{mM}$ each dNTP, 1X buffer, $2 \mathrm{mM} \mathrm{MgCl} 2$ and $1 \mathrm{U}$ Taq DNA polymerase (Invitrogen Life Technologies, Carlsbad, CA, USA). Cycling was performed in a Techne TC-4000 Thermal Cycler (Bibby Scientific Limited, Staffordshire, UK) as follows: amplification consisted of a 2-minute denaturation step at $94^{\circ} \mathrm{C}$; 40 cycles for 60 seconds at $94{ }^{\circ} \mathrm{C}, 40$ seconds at $58{ }^{\circ} \mathrm{C}, 60$ seconds at $72{ }^{\circ} \mathrm{C}$ and final extension of 7 minutes at $72{ }^{\circ} \mathrm{C}$ followed by cooling to $4{ }^{\circ} \mathrm{C}$.

Genotype analysis of three IL28B gene loci (rs12979860, rs12980275 and rs8099917 was conducted using restriction fragment length polymorphism for all three polymorphic loci. PCR products were digested with specific restriction enzymes: BstU I for rs12979860, Bsl I for rs12980275, and Mae III for rs8099917. The digested PCR products were resolved by electrophoresis on $2.5 \%$ agarose gels containing $0.5 \mu \mathrm{g} / \mathrm{mL}$ ethidium bromide. Restriction fragments were visualized with the use of a Vilber-Lourmat Gel Quantification and Documentation System QUANTUM-ST4 (Vilber Lourmat BP 66 Torcy, France).

\section{Statistical Analysis}

Statistical analysis was performed by SPSS 16.0 Software (SPSS Inc., Chicago, IL, USA). The distribution of IL28B gene polymorphisms between HCV patients and healthy controls and their deviations from Hardy-Weinberg equilibrium were compared by using the Fisher's exact chi-square test. A p value of less than 0.05 was considered statistically significant.

Odds ratios (ORs) and 95\% confidence intervals (Cls) were used to determine the association of IL28B allelic and genotypic variants, compound genotypes and haplotypes with the occurrence of HCV disease were also calculated by Win PEPI version 11.39 software. 


\section{Results}

Seventy-four patients completed treatment with PeglFN-a plus RBV (two patients could not receive the treatment because of the side effects). There was no significant difference between the patient and the control group in terms of age, gender, and viral genotype ( $p>0.05)$. Genotype and allele frequencies are given in Table 1. SNP rs12979860 C allele (OR, 0.56; 95\% Cl, 0.37-0.83; $\mathrm{p}<0.005$ ) and $\mathrm{CC}$ genotype (OR, 0.42; 95\% Cl, 0.23-0.77; $\mathrm{p}<0.006$ ); rs12980275 A allele (OR, 0.57; 95\% Cl, 0.38-0.87; $\mathrm{p}<0.009$ ) and GG genotype (OR, 3.96; 95\% Cl, 1.41-11.12; $\mathrm{p}<0.007$ ); rs8099917
T allele (OR, 0.56; 95\% Cl, 0.36-0.88; $\mathrm{p}<0.014$ ) and $\Pi \mathrm{T}$ genotype $(\mathrm{OR}, 0.50 ; 95 \% \mathrm{Cl}, 0.28-0.87 ; \mathrm{p}<0.022)$ were strongly associated with the disease development compare to controls.

To evaluate the clinical applicability of individual SNPs, we calculated the predictive ORs for each SNP between rapid RVR, early virologic response, and SVR (Table 2, 3, 4). There were 25 patients who had spontaneous viral clearance. Rapid viral response was seen in 27 patients who had SNP rs12979860 CT genotype ( $p=0.010)$, rs 12980275 GA genotype ( $p=0.010)$, and both rs8099917 GT and TT genotypes ( $\mathrm{p}=0.019, \mathrm{p}=0.020$, respectively)

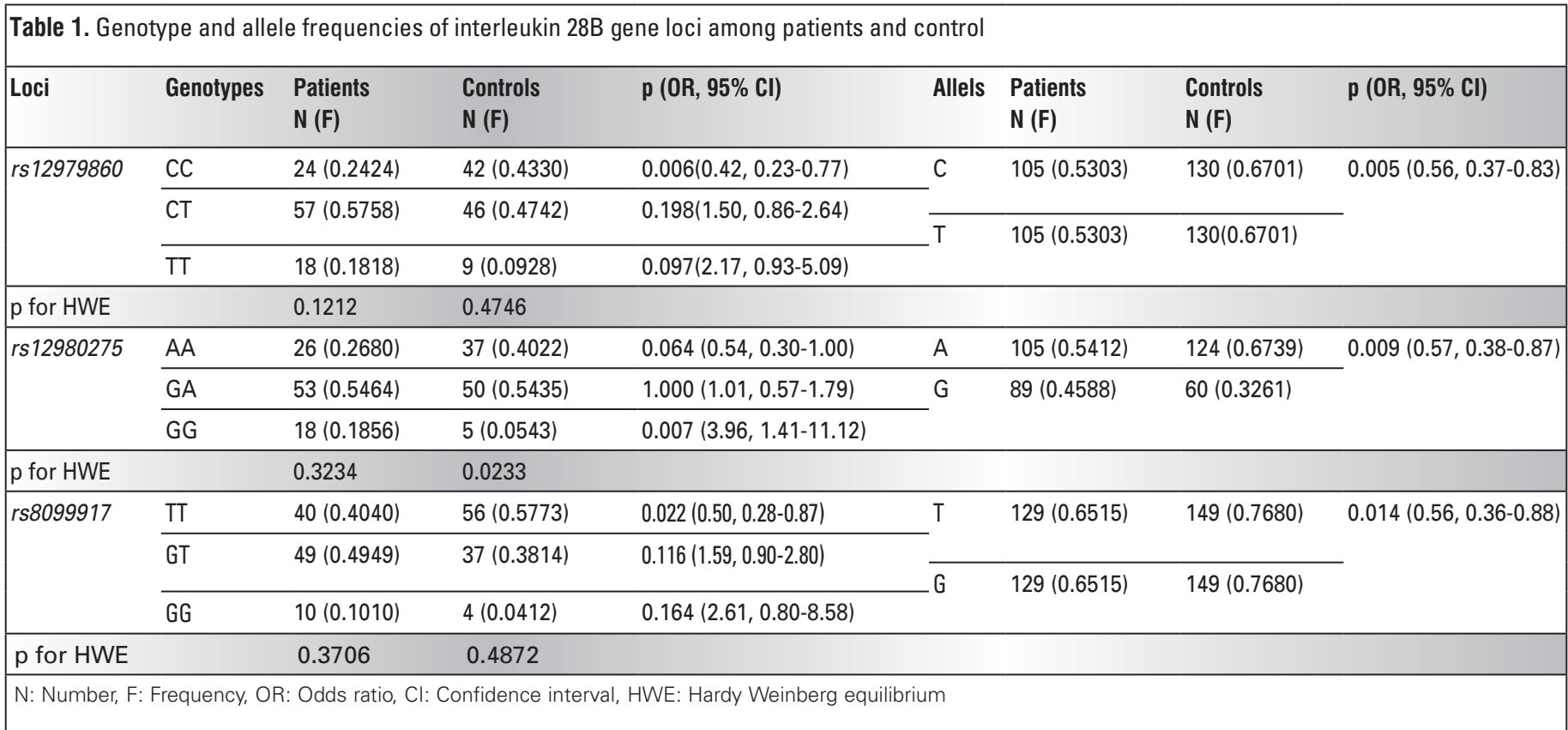

Table 2. Genotype and allele frequencies of interleukin 28B- rs12979860 for disease symptoms

\begin{tabular}{|c|c|c|c|c|c|c|}
\hline \multirow[b]{2}{*}{ CC } & & \multicolumn{3}{|l|}{ Genotypes } & \multicolumn{2}{|l|}{ Alleles } \\
\hline & & CT & $T T$ & C & $T$ & \\
\hline Patients & $\mathrm{CHC}(\mathrm{n}=73)$ & $14(0.1918)$ & $45(0.6164)$ & $14(0.1918)$ & $73(0.5000)$ & $73(0.5000)$ \\
\hline $\mathrm{p}$ & & 0.057 & 0.161 & 1.000 & 0.189 & \\
\hline OR, 95\% Cl & & $0.36,0.13-0.94$ & $2.05,0.83-5.05$ & $1.25,0.38-4.12$ & $0.61,0.32-1018$ & \\
\hline $\mathrm{p}$ & & 0.060 & 0.010 & 0.240 & 0.719 & \\
\hline OR, 95\% Cl & & $3.75,1.03-13.67$ & $0.23,0.08-0.65$ & $2.11,0.64-6.89$ & $1.20,0.60-2.43$ & \\
\hline \multirow[t]{2}{*}{ EVR } & Yes (58) & $13(0.2241)$ & $32(0.5517)$ & $13(0.2241)$ & $58(0.5000)$ & $58(0.5000)$ \\
\hline & No (5) & 0 & $4(0.8000)$ & $1(0.2000)$ & $4(0.4000)$ & $6(0.6000)$ \\
\hline SVR & No (17) & $4(0.2353)$ & $9(0.5294)$ & $4(0.2353)$ & $17(0.5000)$ & $17(0.5000)$ \\
\hline$p$ & & 0.739 & 0.780 & 1.000 & 1.000 & \\
\hline OR, 95\% Cl & & $0.81,0.22-3.00$ & $1.22,0.41-3.63$ & $0.93,0.26-3.37$ & $0.96,0.44-2.09$ & \\
\hline
\end{tabular}


predicted the most positive response to treatment outcome in the overall study population.

We did not find any difference between aspartate aminotransferase/platelet ratio index (APRI) and genotype frequencies.

\section{Discussion}

HCV infection is a major health problem worldwide. The virus is the main cause of chronic hepatitis and liver cirrhosis. Studies on entire viral genomes split HCV into seven major genotypes (22).

\begin{tabular}{|c|c|c|c|c|c|c|}
\hline \multirow[b]{2}{*}{ GG } & & \multicolumn{3}{|l|}{ Genotypes } & \multicolumn{2}{|l|}{ Alleles } \\
\hline & & GA & AA & G & A & \\
\hline & $\begin{array}{l}\text { Carriers } \\
(\mathrm{n}=24)\end{array}$ & $5(0.2083)$ & $10(0.4167)$ & $9(0.3750)$ & $20(0.4167)$ & $28(0.5833)$ \\
\hline $\mathrm{p}$ & & 0.768 & 0.166 & 0.196 & 0.616 & \\
\hline \multirow[t]{2}{*}{ RVR } & Yes (27) & $8(0.2963)$ & $9(0.3333)$ & $10(0.3704)$ & $26(0.4727)$ & $29(0.5273)$ \\
\hline & No (35) & $5(0.1429)$ & $24(0.6857)$ & $6(0.1714)$ & $34(0.4857)$ & $36(0.5143)$ \\
\hline $\mathrm{p}$ & & 0.209 & 0.010 & 0.089 & 1.000 & \\
\hline $\mathrm{OR}, 95 \% \mathrm{Cl}$ & & $2.53,0.73-8.70$ & $0.23,0.08-0.66$ & $2.84,0.89-9.04$ & $0.95,0.47-1.91$ & \\
\hline OR, 95\% Cl & & $1.07,0.4-8.36$ & $0.26,0.03-1.96$ & $4.37,0.29-65.25$ & $0.58,0.17-2.03$ & \\
\hline \multirow[t]{2}{*}{ SVR } & Yes (44) & $9(0.2045)$ & $24(0.5455)$ & $11(0.2500)$ & $42(0.5385)$ & $36(0.4615)$ \\
\hline & No (17) & $4(0.2353)$ & $8(0.4706)$ & $5(0.2941)$ & $16(0.4706)$ & $18(0.5294)$ \\
\hline$p$ & & 1.000 & 0.776 & 0.752 & 0.543 & \\
\hline OR, $95 \% \mathrm{Cl}$ & & $0.84,0.23-3.09$ & $1.35,0.45-4.03$ & $0.80,0.24-2.70$ & $1.31,0.59-2.91$ & \\
\hline
\end{tabular}

Table 4. Genotype and allele frequencies of interleukin 28B- rs8099917 for disease symptoms

\begin{tabular}{|c|c|c|c|c|c|c|}
\hline \multirow{2}{*}{ GG } & & \multicolumn{3}{|l|}{ Genotypes } & \multicolumn{2}{|l|}{ Alleles } \\
\hline & & GT & TT & G & $T$ & \\
\hline \multirow[t]{2}{*}{ Patients } & $\mathrm{CHC}(\mathrm{n}=73)$ & $7(0.0959)$ & $42(0.5753)$ & $24(0.3288)$ & $56(0.3836)$ & $90(0.6164)$ \\
\hline & $\begin{array}{l}\text { Carriers } \\
(n=25)\end{array}$ & $3(0.1200)$ & $7(0.2800)$ & $15(0.6000)$ & $13(0.2600)$ & $37(0.7400)$ \\
\hline $\mathrm{p}$ & & 0.712 & 0.019 & 0.020 & 0.126 & \\
\hline OR, $95 \% \mathrm{Cl}$ & & $0.78,0.19-3.19$ & $3.48,1.32-9.21$ & $0.33,0.13-0.82$ & $1.77,0.87-3.60$ & \\
\hline \multirow[t]{2}{*}{ RVR } & Yes (27) & $3(0.1111)$ & $11(0.4400)$ & $13(0.4815)$ & $17(0.3148)$ & $37(0.6852)$ \\
\hline & No (36) & $4(0.1111)$ & $23(0.6389)$ & $9(0.2500)$ & $31(0.4306)$ & $41(0.5694)$ \\
\hline $\mathrm{p}$ & & 1.000 & 0.190 & 0.067 & 0.200 & \\
\hline $\mathrm{OR}, 95 \% \mathrm{Cl}$ & & $1.00,0.21-4.76$ & $0.44,0.16-1.24$ & $2.79,0.98-7.96$ & $0.61,0.29-1.27$ & \\
\hline \multirow[t]{2}{*}{ EVR } & Yes (58) & $7(0.1207)$ & $29(0.5000)$ & $22(0.3793)$ & $43(0.3707)$ & $73(0.6293)$ \\
\hline & No (5) & 0 & $5(1.0000)$ & 0 & $5(0.5000)$ & $5(0.5000)$ \\
\hline $\mathrm{p}$ & & 1.000 & 0.056 & 0.153 & 0.503 & \\
\hline OR, 95\% Cl & & $1.60,0.10-25.05$ & $0.09,0.01-1.34$ & $6.78,0.46-100.26$ & $0.59,0.17-2.02$ & \\
\hline \multirow[t]{2}{*}{ SVR } & Yes (45) & $5(0.1111)$ & $24(0.5333)$ & $16(0.3556)$ & $34(0.3778)$ & $56(0.6222)$ \\
\hline & No (17) & $2(0.1176)$ & $10(0.5882)$ & $5(0.2941)$ & $14(0.4118)$ & $20(0.5882)$ \\
\hline$p$ & & 1.000 & 0.780 & 0.768 & 0.837 & \\
\hline OR, 95\% Cl & & $0.94,0.17-5.14$ & $0.80,0.27-2.41$ & $1.32,0.41-4.30$ & $0.87,0.39-1.92$ & \\
\hline
\end{tabular}


The HCV genotype 1 is the most prevalent genotype worldwide (46\% of all HCV cases), followed by genotype 3 (30\%) but the distribution of these genotypes are different between countries (23).

Human hepatocytes are the primary target cell for $\mathrm{HCV}$ infection. The first line of immune defense comprises activation of innate immunity following HCV recognition. Local production of IFNs disrupts HCV genome replication and spreading in the liver parenchyma (24). The rate of the treatment of chronic HCV infection (SVR) varies under the influence of ethnicity. For example, it was found that patients of European ancestry were cured more successfully than patients of African ancestry (25).

Besides ethnicity, genetic polymorphism of certain genes influences treatment response. A cohort study with 1000 patients infected with HCV genotype 1 revealed that carrying the IL28B rs12979860 CC genotype was associated with two-fold chance of SVR compared to $\Pi$ genotype (13). Its effect has been shown in HCV+HIV co-infected patients as well $(25,26)$. This CC genotype was also reported to be associated with a higher rate of spontaneous clearance in European and Asian populations $(20,27)$. On the other hand, these significant SNPs observed in Europe and Asia were not strongly associated with Japanese population (17). Moreover, it was found that genomic ancestry did not interfere with therapy response among $\mathrm{HCV}$ genotype 1 patients with $\mathrm{C} / \mathrm{C}$ genotype in a Brazilian study (28).

The frequency of homozygote genotype (rs12979860 CC) is different among countries (29). It is found in $24.2 \%$ of the patient group and $43.3 \%$ of the control group in our study. In a German study, the rs 12979860 CC was 33.9\% in genotype 1 and $49 \%$ in the control group, which is pretty much, same as in our study (30). When we compared the genotype frequencies between the each group, rs 12979860 CC, rs 12980275 GG, and rs8099917 GT genotypes and rs12979860 C, rs12980275 A, and rs8099917 T alleles were found to be higher in the patients but rs12979860 CT (57.6\%), rs12980275 GA genotype (54.6\%); and rs8099917 GT genotypes were the most common genotypes and all were associated with RVR and the RVR was found to be the best indicator for treatment outcome (31).

The main focus of the present study was the importance of the SNP of the IL28B gene. However, not only the rs12979860 CC variability may influence the treatment response but also the rs12980275 and rs8099917. We wanted to bring out the importance of differences between variabilities among countries so that, focusing only the rs12979860 CC genotype should not accurately identify those patients who would respond to the therapy and who would not need longer treatment period. Although our study revealed results consistent with that in many studies, the frequency of the rs 12979860 CC genotype has been found lower in HCV genotype 1 vs. genotype 2/3 patients in a German study (30). It was the same in a Spanish cohort: the CC genotype was overrepresented among patients infected with viral genotypes non-1 (66.7\% versus $39.1 \%$ in patients) (32). In Taiwan, not the rs12979860 but the rs8099917 TT genotype had benefit from a shorter duration of combination therapy in HCV-1 patients (33). In Uzbekistan, SNP rs8099917 was found the most predictive of outcome for Central Asians (18) and in chile, all the three genotypes (the IL28B rs12979860 CC, rs12980275 AA and rs8099917 TT) have been found frequent in patients with SVR compared to null responders (38\%, $44 \%$ and $50 \%$ vs. $2 \%, 8.2 \%$ and $8.2 \%$, respectively) (34). Two recent studies have failed to show such an association: status of IL-28B polymorphism neither affected nor had an impact on virologic response in France and Japan $(35,36)$.

In this study, we also evaluated fibrosis. Although we did not search $\mathrm{HAl}$ and Ishak fibrosis scoring, based on APRI, there was no association observed in terms of fibrosis and IL28B polymorphism in this study. A study observed an association between IL28B and fibrosis progression in CHC patients with IL28B CC genotype had significantly higher portal inflammation (2.4 versus 2.2) and ALT levels (37).

\section{Study Limitations}

The study was conducted before the start of the use of new treatments.

\section{Conclusion}

The determination of IL28B polymorphisms may be useful to individualize treatment options when using Peg/RBV-based therapies for $\mathrm{CHC}$ but countries must know their population's genetic characteristics.

\section{Acknowledgements}

This study has received financial support from the Gaziosmanpaşa University Scientific Research Support Fund. The Ethics Committee of Gaziosmanpaşa University approved the present study and all patients gave written informed consents for the study.

\section{Ethics}

Ethics Committee Approval: The study were approved by the Gaziosmanpaşa University of Local Ethics Committee, Informed Consent: Consent form was filled out by all participants.

Peer-review: Externally and Internally peer-reviewed.

\section{Authorship Contributions}

Medical Practices: Aydın Rüstemoğlu, Özgür Günal, Concept: Aydın Rüstemoğlu, Özgür Günal, Didem Yalçın, Design: Özgür Günal, Didem Yalçın, Betül Çelik, Data Collection or Processing: Şener Barut, Ömer Ateş, Analysis or Interpretation: Didem Yalçın, Betül Çelik, Literature Search: Aydın Rüstemoğlu, Şener Barut, Ömer Ateş, Writing: Özgür Günal, Didem Yalçın, Betül Çelik.

Conflict of Interest: No conflict of interest was declared by the authors.

Financial Disclosure: This study has receieved financial support from.

\section{References}

1. Cybula M, Szemraj J. The role of hepcidin and polymorphisms in the regulatory region of the IL-28B gene in HCV infections. Postepy Hig Med Dosw (Online). 2013;67:1273-1282.

2. Buti $M$, Esteban R. Hepatitis $C$ virus genotype 3: a genotype that is not 'easy-to-treat'. Expert Rev Gastroenterol Hepatol. 2015;9:375385.

3. Stattermayer AF, Scherzer T, Beinhardt $\mathrm{S}$, Rutter $\mathrm{K}$, Hofer $\mathrm{H}$, Ferenci P. Review article: genetic factors that modify the outcome of viral hepatitis. Aliment Pharmacol Ther. 2014;39:1059-1070. 
4. Kelly C, Klenerman P, Barnes E. Interferon lambdas: the next cytokine storm. Gut. 2011;60:1284-1293.

5. Di Bisceglie AM. Natural history of hepatitis C: its impact on clinical management. Hepatology. 2000;31:1014-1018.

6. Gerlach JT, Diepolder HM, Zachoval R, Gruener NH, Jung MC, Ulsenheimer A, Schraut WW, Schirren CA, Waechtler M, Backmund M, Pape GR. Acute hepatitis C: high rate of both spontaneous and treatment-induced viral clearance. Gastroenterology. 2003;125:80-88.

7. Micallef JM, Kaldor JM, Dore GJ. Spontaneous viral clearance following acute hepatitis C infection: a systematic review of longitudinal studies. J Viral Hepat. 2006;13:34-41.

8. Saito $T$, Ueno $Y$. Transmission of hepatitis $C$ virus: self-limiting hepatitis or chronic hepatitis? World J Gastroenterol. 2013;19:69576961.

9. Manns MP, Wedemeyer $H$, Cornberg M. Treating viral hepatitis C: efficacy, side effects, and complications. Gut. 2006;55:1350-1359.

10. Stättermayer AF, Ferenci P. Effect of IL28B genotype on hepatitis $B$ and $C$ virus infection. Curr Opin Virol. 2015;14:50-55.

11. Molecular Epidemiology and Genotype Distribution of Hepatitis $C$ Virus of Turkey as Reflected by Phylogenetic Analysis of the NS5B Region, E1 Region and 5'UTR Region. Saliha Gokce Kabakci, MD, Ankara, 2011.

12. Hepatit C Virus Genotype and its relationship with Alanine aminotranspherase and HCV_RNA. Mustafa Fatih Kucukoztas, MD, Istanbul, 2008.

13. Ge D, Fellay J, Thompson AJ, Simon JS, Shianna KV, Urban TJ, Heinzen EL, Qiu P, Bertelsen AH, Muir AJ, Sulkowski M, McHutchison JG, Goldstein DB. Genetic variation in IL28B predicts hepatitis C treatment-induced viral clearance. Nature. 2009;461:399-401.

14. Rauch A, Kutalik Z, Descombes P, Cai T, Di lulio J, Mueller T, Bochud M, Battegay M, Bernasconi E, Borovicka J, Colombo S, Cerny A, Dufour JF, Furrer $H$, Günthard HF, Heim $M$, Hirschel $B$, Malinverni R, Moradpour D, Müllhaupt B, Witteck A, Beckmann JS, Berg T, Bergmann S, Negro F, Telenti A, Bochud PY; Swiss Hepatitis C Cohort Study; Swiss HIV Cohort Study. Genetic variation in IL28B is associated with chronic hepatitis $\mathrm{C}$ and treatment failure: a genomewide association study. Gastroenterology. 2010;138:1338-1345.

15. Suppiah V, Moldovan M, Ahlenstiel G, Berg T, Weltman M, Abate ML, Bassendine M, Spengler U, Dore GJ, Powell E, Riordan S, Sheridan D, Smedile A, Fragomeli V, Müller T, Bahlo M, Stewart GJ, Booth DR, George J. IL28B is associated with response to chronic hepatitis C interferon-alpha and ribavirin therapy. Nat Genet. 2009;41:1100-1104.

16. Tanaka Y, Nishida N, Sugiyama M, Kurosaki M, Matsuura K, Sakamoto N, Nakagawa M, Korenaga M, Hino K, Hige S, Ito Y, Mita E, Tanaka E, Mochida S, Murawaki Y, Honda M, Sakai A, Hiasa Y, Nishiguchi S Koike A, Sakaida I, Imamura M, Ito K, Yano K, Masaki N, Sugauchi F, Izumi N, Tokunaga K, Mizokami M. Genome-wide association of IL28B with response to pegylated interferon-alpha and ribavirin therapy for chronic hepatitis C. Nat Genet. 2009;41:1105-1109.

17. Sugiyama M, Mizokami M. Genome-wide association study on and the clinical application to chronic hepatitis C. Uirusu. 2011;61:15-24.

18. Khudayberganova D, Sugiyama M, Masaki N, Nishida N, Mukaide M, Sekler D, Latipov R, Nataliya K, Dildora S, Sharapov S, Usmanova G, Raxmanov M, Musabaev E, Mizokami M. IL28B polymorphisms and clinical implications for hepatitis $\mathrm{C}$ virus infection in Uzbekistan. PLoS One. 2014;9:e93011.

19. Faruki H, Albrecht J, Morrison P, et al. Genotype frequencies of IL28B genetic polymorphisms rs12979860 and rs809917 in a large genetic database of various ethnic/racial origin individuals. Hepatology, 54, 816A, 2011.

20. Alestig E, Arnholm B, Eilard A, Lagging M, Nilsson S, Norkrans G, Wahlberg T, Wejstål R, Westin J, Lindh M. Core mutations, IL28B polymorphisms and response to peginterferon/ribavirin treatment in Swedish patients with hepatitis C virus genotype 1 infection. BMC Infect Dis. 2011:11:124.

21. European Association for Study of Liver. EASL Clinical Practice Guidelines: management of hepatitis C virus infection. J Hepatol. 2014;60:392-420.
22. Smith DB, Bukh J, Kuiken C, Muerhoff AS, Rice CM, Stapleton JT, Simmonds P. Expanded classification of hepatitis $C$ virus into 7 genotypes and 67 subtypes: updated criteria and genotype assignment web resource. Hepatology. 2014;59:318-327.

23. Venegas M, Brahm J, Villanueva RA. Genomic determinants of hepatitis C virus antiviral therapy outcomes: toward individualized treatment. Ann Hepatol. 2012;11:827-837.

24. Horner SM, Gale M. Regulation of hepatic innate immunity by hepatitis C virus. Nat Med. 2013;19:879-888.

25. Kanwal F, White DL, Tavakoli-Tabasi S, Jiao L, Lin D, Ramsey DJ, Spiegelman A, Kuzniarek J, El-Serag HB. Many patients with interleukin 28B genotypes associated with response to therapy are ineligible for treatment because of comorbidities. Clin Gastroenterol Hepatol. 2014;12:327-333.e1.

26. Dayyeh BK, Gupta N, Sherman KE, de Bakker PI, Chung RT; Aids Clinical Trials Group A5178 Study Team. IL28B alleles exert an additive dose effect when applied to HCV-HIV coinfected persons undergoing peginterferon and ribavirin therapy. PLoS One. 2011;6:e25753.

27. Hung $\mathrm{CH}$, Chang $\mathrm{KC}$, Lu SN, Wang JH, Chen $\mathrm{CH}$, Lee $\mathrm{CM}$, Hu TH. Spontaneous clearance of hepatitis C virus in an interleukin 28B favorable genotype highly prevalent area. Hepatology. 2013;57:20892090.

28. Cavalcante LN, Abe-Sandes $K$, Angelo AL, Machado TM, Lemaire DC, Mendes CM, Pinho JR, Malta F, Lyra LG, Lyra AC. IL28B polymorphisms are markers of therapy response and are influenced by genetic ancestry in chronic hepatitis $\mathrm{C}$ patients from an admixed population. Liver Int. 2012;32:476-486.

29. Rangnekar AS, Fontana RJ. Meta-analysis: IL-28B genotype and sustained viral clearence in HCV genotype 1 patients. Aliment Pharmacol Ther. 2012;36:104-114.

30. Sarrazin C, Susser S, Doehring A, Lange CM, Müller T, Schlecker C, Herrmann E, Lötsch J, Berg T. Importance of IL28B gene polymorphisms in hepatitis $\mathrm{C}$ virus genotype 2 and 3 infected patients. J Hepatol. 2011;54:415-421.

31. Poordad F, Bronowicki JP, Gordon SC, Zeuzem S, Jacobson IM, Sulkowski MS, Poynard T, Morgan TR, Molony C, Pedicone LD, Sings $\mathrm{HL}$, Burroughs MH, Sniukiene V, Boparai N, Goteti VS, Brass CA, Albrecht JK, Bacon BR; SPRINT-2 and RESPOND-2 Investigators. Factors that predict response of patients with hepatitis $\mathrm{C}$ virus infection to boceprevir. Gastroenterology. 2012;143:608-618.e1-5.

32. Montes-Cano MA, Garcca-Lozano JR, Abad-Molina C, RomeroGomez M, Barroso N, Aguilar-Reina J, Nunez-Roldan A, GonzalezEscribano MF. Interleukin-28B genetic variants and hepatitis virus infection by different viral genotypes. Hepatology. 2010;52:33-37.

33. Liu CH, Liang CC, Liu CJ, Tseng TC, Lin CL, Yang SS, Su TH, Hsu SJ, Lin JW, Chen JH, Chen PJ, Chen DS, Kao JH. Interleukin 28B genetic polymorphisms and viral factors help identify HCV genotype-1 patients who benefit from 24-week pegylated interferon plus ribavirin therapy. Antivir Ther. 2012;17:477-484.

34. Venegas M, Villanueva RA, Gonzalez K, Brahm J. IL28B polymorphisms associated with therapy response in Chilean chronic hepatitis $C$ patients. World J Gastroenterol. 2011;17:3636-3639.

35. Nishiguchi $S$, Enomoto $H$, Aizawa N, Nishikawa $H$, Osaki $Y_{\text {, Tsuda }} Y_{i}$ Higuchi K, Okazaki K, Seki T, Kim SR, Hongo Y, Jyomura H, Nishida $N$, Kudo M. Relevance of the Core 70 and IL-28B polymorphism and response-guided therapy of peginterferon alfa-2a \pm ribavirin for chronic hepatitis $\mathrm{C}$ of Genotype $1 \mathrm{~b}$ : a multicenter randomized trial, ReGIT-J study. J Gastroenterol. 2014;49:492-501.

36. Pol S, Aerssens J, Zeuzem S, Andreone P, Lawitz EJ, Roberts S, Younossi Z, Foster GR, Focaccia R, Horban A, Pockros PJ, Van Heeswijk RP, De Meyer S, Luo D, Botfield M, Beumont M, Picchio G. Limited impact of IL28B genotype on response rates in telaprevir-treated patients with prior treatment failure. J Hepatol. 2013;58:883-889.

37. Noureddin $\mathrm{M}$, Wright EC, Alter HJ, Clark S, Thomas E, Chen R, Zhao X, Conry-Cantilena C, Kleiner DE, Liang TJ, Ghany MG. Association of IL28B genotype with fibrosis progression and clinical outcomes in patients with chronic hepatitis C: a longitudinal analysis. Hepatology. 2013;58:1548-1557. 